\title{
Expression, purification and characterization of Oryza sativa L. NAD-malic enzyme in Escherichia coli
}

\author{
Hao Zhou', Shenkui Liu ${ }^{2}$ and Chuanping Yang ${ }^{1 *}$ \\ ${ }^{1}$ State Key Laboratory of Forest Tree Genetic Improvement and Biotechnology, Northeast Forestry University, Harbin, \\ 150040, Heilongjiang Province, P.R. China. \\ ${ }^{2}$ Alkali Soil Natural Environmental Science Center (ASNESC), Northeast Forestry University, Harbin, 150040, \\ Heilongjiang Province, P.R. China.
}

Accepted 26 August, 2011

\begin{abstract}
The cDNA fragment of a rice NAD-malic enzyme (OSNAD-ME $)_{1}$ was cloned and constructed into expression vector ( $p G E X-6 p-3$ ). OsNAD-ME ${ }_{1}$ was successfully expressed as a GST fusion protein in Escherichia coli BL21. The optimal concentration of IPTG for inducement was $1 \mathrm{mmol} / \mathrm{L}$ and the optimal culture temperature was $30^{\circ} \mathrm{C}$. The fusion protein was purified by using affinity chromatography with a glutathione sepharose 4B column. After enzymatic cleavage of GST tag, the OSNAD-ME ${ }_{1}$ recombinant protein was collected for studying its kinetic properties. The optimum $\mathrm{pH}$ and temperature for catalytic reaction of OsNAD-ME ${ }_{1}$ were $\mathrm{pH} 6.4$ and $35^{\circ} \mathrm{C}$, respectively. The $k_{\text {cat }}$ value determined at $\mathrm{pH} 6.4$ was $36.38 \mathrm{~s}^{-1}$ and the $K_{\mathrm{m}}$ values for $\mathrm{NAD}^{+}$and malate were 0.10 and $15.98 \mathrm{mmol} / \mathrm{L}$, respectively. The maximum activity of OsNAD-ME ${ }_{1}$ using $\mathrm{NADP}^{+}$as coenzyme was $64.47 \%$ of that using $\mathrm{NAD}^{+}$as coenzyme.
\end{abstract}

Key words: Enzyme activity, GST fusion protein, kinetic properties, NAD-malic enzyme, Oryza sativa L., purification.

\section{INTRODUCTION}

Malic enzymes (MEs) widely distributed in nature, have been identified in different organisms, such as bacteria, yeast, fungi, plants, animals and humans. MEs catalyze the oxidative decarboxylation of L-malate to pyruvate in the presence of cations (typically $\mathrm{Mg}^{2+}$ or $\mathrm{Mn}^{2+}$ ) with the concomitant reduction of coenzyme $\mathrm{NAD}^{+}$or $\mathrm{NADP}^{+}$(Lmalate $+\mathrm{NAD}(\mathrm{P})^{+}$Pyruvate $\left.+\rightleftharpoons \mathrm{CO}_{2}+\mathrm{NAD}(\mathrm{P}) \mathrm{H}+\mathrm{H}^{+}\right)$ (Chang and Tong, 2003). Based on their coenzyme specificities and abilities to decarboxylate oxaloacetate (OAA), MEs can be divided into three categories: EC 1.1.1.38 (NAD ${ }^{+}$dependent; decarboxylates OAA), EC 1.1.1.39 (prefers $\mathrm{NAD}^{+}$rather than $\mathrm{NADP}^{+}$; does not decarboxylate OAA) and EC 1.1.1.40 (NADP ${ }^{+}$dependent; decarboxylates added OAA) (Fukuda et al., 2005; Bologna et al., 2007). Plant NAD-malic enzymes (NADMEs) including NAD-MEs from ryza sativa L. (OsNADMEs) belong to the EC 1.1.1.39 subtype, as they are not able to decarboxylate OAA (Maurino et al., 2009).

\footnotetext{
${ }^{*}$ Corresponding author. E-mail: yangcp_nefu@yahoo.com.cn.
} Tel: + 86-451-8219 0006. Fax: +86-451-8219 0006.
Their amino acid sequences are also highly conserved among a large number of organisms, suggesting that MEs have important biological functions. In plants, the substrates and products of them are involved in diverse metabolic pathways such as photosynthesis and respiration (Maurino et al., 2009). Moreover, it was considered that plant NADP-malic enzymes (NADP-MEs) were involved in plant defense responses. Plant NADPMEs were induced by many biotic or abiotic stresses, such as pathogen (Sutherland, 1991), wounding, UV-B radiation (Casati et al., 1999), ABA, SA, low temperature, dark, salt and drought stress (Fu et al., 2009). The mechanism about stress resistance was postulated that the enzyme was implicated in defense-related deposition of lignin and flavonoid by providing NADPH for steps in their biosynthesis pathway requiring reductive power (Casati et al., 1999).

There is an increasing volume of available software providing location prediction information for proteins based on amino acid sequence. For instance, NAD-MEs from Arabidopsis thaliana (AtNAD-MEs) were predicted to be localized to mitochondria (Haezlewood et al., 2005, 
2007), which was consistent with the results revealed by a mitochondrial proteomic research (Haezlewood et al., 2004). Some C4 and crassulacean acid metabolism (CAM) plants use mitochondrial NAD-ME to decarboxylate L-malate for increasing the $\mathrm{CO}_{2}$ concentration at the site of RuBisCO. In C3 plants, NAD-ME isoforms have a central function in the mitochondrial metabolism, where they are involved in L-malate respiration (Artus and Edwards, 1985). In fact, the distinction between C3 and C4 plants is not always clear-cut. Many C3 plants, meanwhile, also have several of the genes needed for $\mathrm{C} 4$ photosynthesis, but do not use them in the same way (Marshall et al., 2007; Duvall et al., 2003).

Plant NAD-MEs are separated into two phylogenetically related groups: $\alpha$ and $\beta$. The genome of Oryza sativa L. possesses two genes (OsNAD-ME 1 and OsNAD-ME $E_{2}$ encoding putative NAD-MEs. OsNAD-ME ${ }_{1}$ and OsNAD$\mathrm{ME}_{2}$ display $64.5 \%$ identity and belong to $\alpha$ and $\beta$ group, respectively. All characterized plant NAD-MEs were composed of two dissimilar subunits $(\alpha$ and $\beta$ ) at a 1:1 molar ratio (Tronconi et al., 2008; Willeford and Wedding, 1987; Burnell, 1987; Long et al., 1994; Winning et al., 1994). In potato and Crassula argentea, no activity was associated with the separated subunits (Willeford and Wedding, 1987; Winning et al., 1994), while in A. thaliana the subunits assembled as active homo and heterodimers both in vivo and in vitro (Tronconi et al., 2008). Under denaturing conditions, the enzyme existed as partially unfolded dimers, which were easily polymerized. $\mathrm{Mn}^{2+}$ provided full protection against the polymerization (Chang et al., 2002; Chang and Chaang, 2003).

In present work, the cDNA fragment of OsNAD-ME (Gene ID: 4343294) was cloned and expressed as a fusion protein in Escherichia coli BL21. The kinetic properties of the OsNAD-ME ${ }_{1}$ recombinant protein including optimum temperature, optimum $\mathrm{pH}, k_{\mathrm{cat}}, K_{\mathrm{m} \text { NAD }}$ and $K_{\mathrm{m}}$ malate were determined. Meanwhile, the activities with different coenzymes were determined. So far, OsNAD-ME ${ }_{1}$ has never been over-expressed and biochemically characterized. Therefore, we would like to report the over-expression, purification and kinetic characterization of OsNAD-ME ${ }_{1}$ recombinant protein, which will facilitate a platform for further biochemical research.

\section{MATERIALS AND METHODS}

\section{Construction of expression plasmid}

The cDNA fragment of OsNAD-ME 1 amplified by polymerase chain reaction (PCR) with sense primer (5'-GAATTC GAGATCGATGGCG-3', EcoRI site underlined) and antisense primer (5'-CTCGAGGTCTTTCTTGTACAC-3', Xhol site underlined) was fused into the PMD-18-T (pT) vector (TaKaRa) to construct the pT-OsNAD-ME ${ }_{1}$ plasmid. The pT-OsNAD-ME ${ }_{1}$ plasmid DNA was digested with EcoRI and Xhol, and the digested OsNAD-ME cDNA was inserted into pGEX-6p-3 vector (Amersham Pharmacia Biotech) that was digested with the same enzymes. The recombinant plasmid was designed as pGEX-6p-3OsNAD-ME 1 and transformed into the E. coli BL21.

\section{Expression and purification of recombinant proteins from $E$. coli}

E. coli cells containing pGEX-6p-3-OsNAD-ME 1 plasmid were employed to produce the recombinant proteins with glutathione-Stransferase tag (GST-OsNAD-ME 1 ). The cells cultured in $2 \times \mathrm{YT}$ medium ( $1 \%$ yeast extract, $1.6 \%$ tryptone and $0.5 \% \quad \mathrm{NaCl})$ containing $100 \mu \mathrm{g} / \mathrm{ml}$ ampicillin at $37^{\circ} \mathrm{C}$ overnight were diluted 1:100-fold with fresh pre-warmed $2 \times Y T$ medium supplied with $100 \mu \mathrm{g} / \mathrm{ml}$ ampicillin and allowed to grow with shaking (150 rpm) at $37^{\circ} \mathrm{C}$. When the cell density reached OD600 of 0.8 approximately, isopropyl- $\beta$-D-thiogalactopyranoside (IPTG) was added to a final concentration of $1 \mathrm{mmol} / \mathrm{L}$, and then the cells were cultured for additional $10 \mathrm{~h}$ at $30^{\circ} \mathrm{C}$ for inducement of the expression of GSTOsNAD-ME ${ }_{1}$. The cells were harvested through centrifugation at $6000 \mathrm{~g}$ for $5 \mathrm{~min}$ at $4{ }^{\circ} \mathrm{C}$ and resuspended in pre-cooled lysis buffer (20 mmol/L Tris- $\mathrm{HCl} \mathrm{pH} \mathrm{8.0,} 1 \mathrm{mmol} / \mathrm{L}$ EDTA, $20 \mathrm{mmol} / \mathrm{L} \mathrm{NaCl}, 1 \%$ Triton X-100 and $1 \mathrm{mmol} / \mathrm{L}$ PMSF). And lysozyme (a final concentration of $1 \mathrm{mg} / \mathrm{ml}$ ) was added to the suspension, which then was incubated on ice for $45 \mathrm{~min}$ and centrifuged at $20,000 \mathrm{~g}$ for $1 \mathrm{~h}$. The supernatant (containing GST-OsNAD-ME ${ }_{1}$ fusion proteins) was loaded onto a glutathione-Sepharose-4B column pre-equilibrated

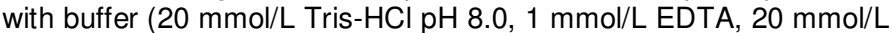
$\mathrm{NaCl}$ and $1 \mathrm{mmol} / \mathrm{L} \mathrm{PMSF})$. Non-specifically bound proteins were removed by washing with buffer above, and the bound fusion proteins with GST tag were recovered from the resin with elution buffer $(50 \mathrm{mmol} / \mathrm{L}$ Tris $-\mathrm{HCl} \mathrm{pH} 8.0$ and $10 \mathrm{mmol} / \mathrm{L}$ reduced glutathione). Enzyme purity was checked with denaturingpolyacrylamide gel electrophoresis (SDS-PAGE) and proteins were visualized with Coomassie Brilliant Blue R-250 staining. The protein concentrations were determined by the method of Bradford using BSA as standard.

\section{Cleavage of the GST tag}

The GST-OsNAD-ME 1 fusion proteins bound to the column were digested by PreScission protease in elution buffer $(50 \mathrm{mmol} / \mathrm{L}$ Tris$\mathrm{HCl} \mathrm{pH} 7.5$ amd $1 \mathrm{mmol} / \mathrm{L}$ PMSF) for $16 \mathrm{~h}$ at $4^{\circ} \mathrm{C}$. The desired OsNAD-ME ${ }_{1}$ recombinant proteins were collected and used for activity tests immediately or stored at minus $80^{\circ} \mathrm{C}$ for later use.

\section{Assay of OsNAD-ME 1 activity}

The OsNAD-ME $E_{1}$ reaction was measured by tracing $\mathrm{NADH}$ production. The standard reaction mixture contained $50 \mathrm{mmol} / \mathrm{L}$ Tris- $\mathrm{HCl}, 10 \mathrm{mmol} / \mathrm{L} \mathrm{MgCl}_{2}, 0.5 \mathrm{mmol} / \mathrm{L} \mathrm{NAD}^{+}$, and $10 \mathrm{mmol} / \mathrm{L} \mathrm{L}$ malate in a final concentration. The reaction was started by adding L-malate. The absorbance at $340 \mathrm{~nm}$ was continuously monitored with Ultrospec 4300 pro UV/visible spectrophotometer. The product concentration was calculated by the following formula:

$$
C(\mathrm{~mol} / \mathrm{L})=\frac{\Delta A \cdot V}{\varepsilon \cdot l \cdot V}
$$

Where, $\Delta A, V, v, \varepsilon$ and $/$ are the change in absorbance during reaction, the final volume, the enzymatic volume, the extinction coefficient and the width of cuvette, respectively. A molar extinction coefficient of $6220 \mathrm{~L} \cdot \mathrm{mol}^{-1} \cdot \mathrm{cm}^{-1}$ for $\mathrm{NADH}$ was employed in the 
(a) $\quad 1 \quad 2 \quad 2 \quad 3 \quad 4 \quad 56 \quad 6 \quad 7$

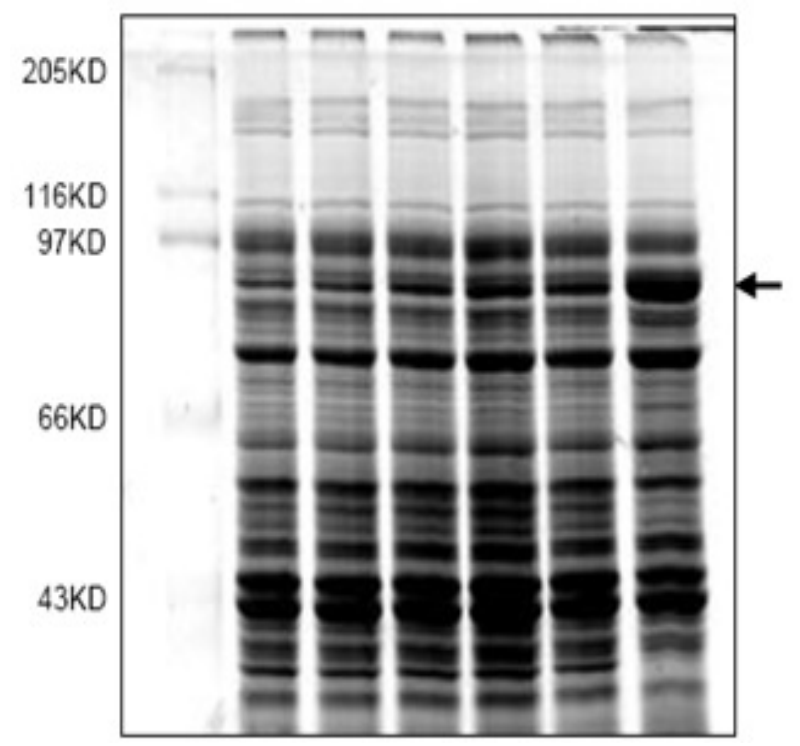

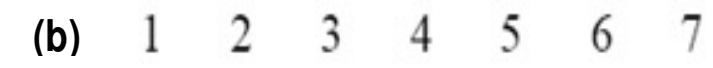

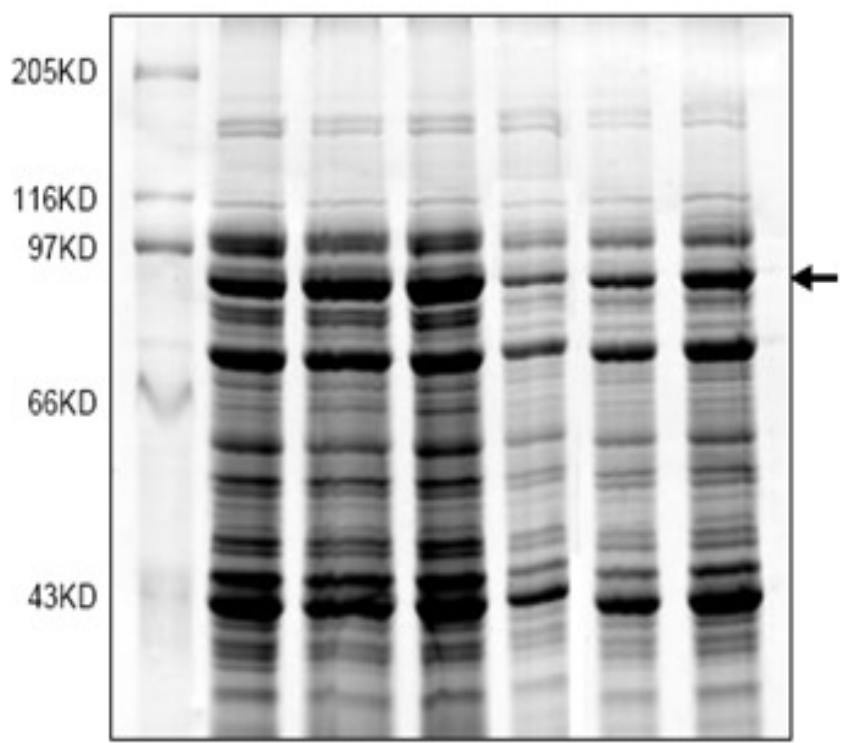

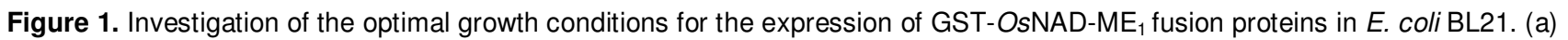
Time course expressions of GST-OSNAD-ME 1 . Bacterial lysates were obtained from E. coli BL21 transformed with pGEX-6P-3OsNAD-ME 1 that were induced with $1 \mathrm{mmol} / \mathrm{L}$ IPTG for different times, and were analyzed on SDS-PAGE. Lane 1, molecular weight markers; lane 2 to 7, IPTG inducement for $0,1,3,5,7$ and $10 \mathrm{~h}$. (b) The effects of IPTG concentration and temperature on the expression of GST-OSNAD-ME ${ }_{1}$. Lane 1, the molecular weight markers. SDS-PAGE analysis of bacterial lysates were obtained from $E$. coli BL21 harboring pGEX-6P-3-OsNAD-ME 1 induced by different IPTG concentrations of $0.1,0.5$ and 1.0 $\mathrm{mmol} / \mathrm{L}$ (Lane 2 to 4 ) and incubated at different temperatures of 22, 26 and $30^{\circ} \mathrm{C}$ (Lane 5 to 7 ). Arrows indicated the expressed GST-OsNAD-ME 1 .

calculations. One unit (katal) of enzyme activity is defined as the amount of enzyme resulting in the production of $1 \mathrm{~mol}$ of $\mathrm{NADH}$ per second. Turnover number $\left(k_{\text {cat }}\right)$ is defined as the maximum number of molecules of substrate that an enzyme can convert to product per catalytic site per unit of time and can be calculated as follows:

$$
k_{\text {cat }}\left(S^{-1}\right)=\frac{C}{t \cdot[E]}
$$

Where, $C, t$ and $[E]$ are the product concentration, the reaction time and the enzyme molar concentration, respectively.

\section{Kinetic studies on OsNAD-ME 1}

Apparent Michaelis constants $\left(K_{\mathrm{m} \text {,malate }}\right.$ and $\left.K_{\mathrm{m}, \mathrm{NAD}}\right)$ of OsNAD-ME ${ }_{1}$ were determined by varying the concentration of one substrate (or coenzyme) around its $K_{\mathrm{m}}$ value and keeping the other reactants at a constant and saturating concentration. The concentrations of $\mathrm{L}$ malate and $\mathrm{NAD}^{+}$were varied in the ranges of 5 to 100 and 25 to $500 \mu \mathrm{mol} / \mathrm{L}$, respectively. Changes in absorbance during the time taken for the assay were linear by creating Lineweaver-Burk reciprocal plots. The $y$-axis $(1 / \mathrm{V})$ took the reciprocal of the reaction velocity (the product yield per unit of time per unit of volume) and the $x$-axis $(1 /[S])$ took the reciprocal of the substrate concentration. The $x$-intercept of the graph represented $-1 / K_{\mathrm{m}}$. The $K_{\mathrm{m}}$ values of OsNAD-ME ${ }_{1}$ against $\mathrm{NAD}^{+}$and L-malate were calculated, respectively. All the values were the means of three independent replications.

\section{RESULTS AND DISCUSSION}

\section{Expression and purification of recombinant proteins}

Expression of OsNAD-ME ${ }_{1}$ as a GST fusion protein in $E$. coli BL21 cells harboring plasmid pGEX-6p-3-OsNAD$\mathrm{ME}_{1}$ was induced by IPTG. The GST-OsNAD-ME ${ }_{1}$ fusion protein had a molecular mass of $88 \mathrm{kDa}$ (arrow in Figure 1 ), which was consistent with the sum of the molecular masses of GST (26 kDa) and OsNAD-ME ${ }_{1}(62 \mathrm{kDa})$ predicted from their nucleotide sequences.

In order to obtain enough recombinant protein for following study, optimal expression conditions were examined, including concentration of IPTG for inducement together with culture temperature and time for inducement. The amount of GST-OsNAD-ME ${ }_{1}$ increased during the $10 \mathrm{~h}$ after induced by IPTG (Figure 1a) and then stabilized. It showed that the optimal culture time of cells for inducement was $10 \mathrm{~h}$. A range of temperature from 16 to $37^{\circ} \mathrm{C}$ was attempted for obtaining the optimal growth temperature. It was found that the yield of GSTOsNAD-ME1 was very low at lower (blow $20^{\circ} \mathrm{C}$ ) or higher (above $30^{\circ} \mathrm{C}$ ) temperatures. The results in Figure $1 \mathrm{~b}$ displayed the yield of fusion proteins increased gradually in the range of 20 to $30^{\circ} \mathrm{C}$, and the optimal growth temperature for the recombinant $E$. coli cells was $30^{\circ} \mathrm{C}$. The effects of different IPTG concentrations, 


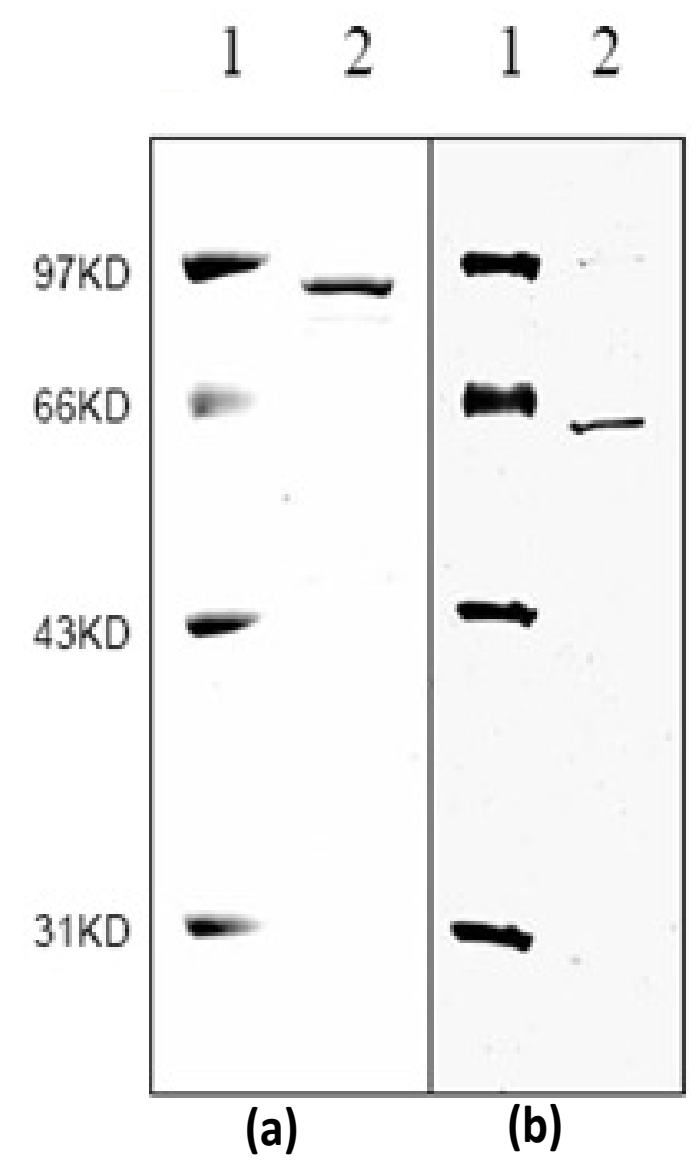

Figure 2. SDS-PAGE analysis of recombinant proteins purified from E. coli BL21. (a) and (b) Lane 1, molecular weight markers; (a) lane 2, the purified GST-OSNAD-ME OsNAD-ME ${ }_{1}$ after cleavage of GST tag

including $0.1,0.5$ and $1.0 \mathrm{mmol} / \mathrm{L}$, on producing GSTOsNAD-ME ${ }_{1}$ were determined. The results show that the expression of fusion proteins decreased at lower IPTG concentration and the optimal IPTG concentration for inducing the expression of GST-OsNAD-ME ${ }_{1}$ was 1.0 $\mathrm{mmol} / \mathrm{L}$ (Figure 1b).

One liter of cells was grown at $30^{\circ} \mathrm{C}$ and harvested by centrifugation after induced by $1.0 \mathrm{mmol} / \mathrm{L} \mathrm{IPTG}$ for $10 \mathrm{~h}$. The collected cells about $2.11 \mathrm{~g}$ wet weight was lysed with lysozyme. After centrifugation, the supernatant was loaded on a glutathione Sepharose 4B column. The fusion proteins specifically bound were eluted with reduced glutathione solution from the column and examined by SDS-PAGE. The GST-OSNAD-ME ${ }_{1}$ homogeneous fusion proteins band ( $88 \mathrm{kDa})$ was obtained on SDS-PAGE (lane 2, Figure 2a). After cleavage of GST tag by PreScission Protease, the OsNAD-ME ${ }_{1}$ recombinant proteins were obtained and analyzed with SDSPAGE. As shown in Figure $2 b$, the recombinant proteins had molecular weight of about $62 \mathrm{kDa}$ (lane2, Figure 2b), which was consistent with the expected.
As shown in table $1,5.78 \mathrm{mg}$ purified OsNAD-ME ${ }_{1}$ were obtained from $1 \mathrm{~L}$ of bacterial culture after two purification steps, which was enough for kinetic characterization. The total activity was $4.35 \mu \mathrm{katal}$ in the crude extract. The recoveries of the first purification step and second purification step were 86.28 and $70.11 \%$, respectively. The total activity of purified OsNAD-ME ${ }_{1}$ reached as high as $3.05 \mu \mathrm{katal}$ and the specific activity reached $527.84 \mu \mathrm{katal} / \mathrm{g}$. The activity of OsNAD-ME ${ }_{1}$ remained stable for at least $8 \mathrm{~h}$ in the temperature about $4^{\circ} \mathrm{C}$.

\section{Characterization of recombinant proteins}

The optimum $\mathrm{pH}$ and temperature for the catalytic reaction of OsNAD-ME ${ }_{1}$ were determined by measuring the oxidative decarboxylation of L-malate at different $\mathrm{pH}$ values and different temperatures under standard conditions, respectively and comparing relative enzyme activities. The relative activity of OsNAD-ME ${ }_{1}$ reached 

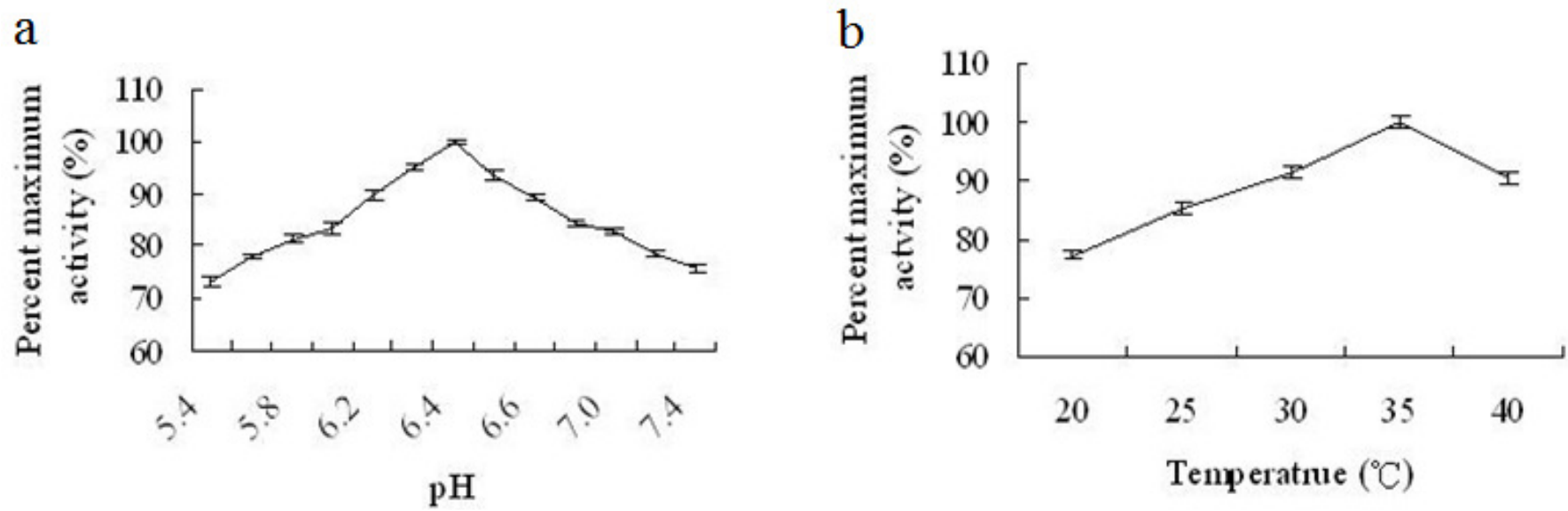

Figure 3. Analysis of the optimum $\mathrm{pH}$ and temperature of purified OsNAD-ME 1 for the catalytic reaction. (a) For the $\mathrm{pH}$ dependent studies, a mixture of $100 \mathrm{mmol} / \mathrm{L}$ of bis-Tris propane and $1 \mathrm{~mol} / \mathrm{L}$ of $\mathrm{HCl}$ were used to obtain solutions with different $\mathrm{pH}$ by adjusting the volumes of bis-Tris propane and $\mathrm{HCl}$; (b) For the temperature dependent studies, each set was treated with one temperature regime. The reaction mixture contained $50 \mathrm{mmol} / \mathrm{L}$ Tris- $\mathrm{HCl}, 10 \mathrm{mmol} / \mathrm{L} \mathrm{MgCl}, 0.5 \mathrm{mmol} / \mathrm{L} \mathrm{NAD}$ and $10 \mathrm{mmol} / \mathrm{L} \mathrm{L}-\mathrm{malate}$ in a final concentration at different $\mathrm{pH}$ values or temperatures tested. Reactions were started by the addition of $\mathrm{L}$-malate. The values indicated the means of three independent replications.

maximum when the value of $\mathrm{pH}$ was 6.4 or the temperature was $35^{\circ} \mathrm{C}$ (Figure 3), thus indicating that the optimum $\mathrm{pH}$ was $\mathrm{pH} 6.4$ and the optimum temperature was $35^{\circ} \mathrm{C}$ for the catalytic reaction. The optimum $\mathrm{pH}$ for purified AtNAD-ME ${ }_{1}$, belonging to a-NAD-ME group as same as OsNAD-ME ${ }_{1}$, was reported also to be 6.4 (Tronconi et al., 2010). In prokaryote, however, the optimum $\mathrm{pH}$ for NAD-ME from E. coli $\mathrm{K} 12$ with regard to L-malate was 7.2 (Wang et al., 2007).

Apparent Michaelis constants of OsNAD-ME ${ }_{1}$ were determined by altering the concentrations of one substrate and keeping the concentrations of other substrates and coenzyme at saturation. When malate was the limiting substrate (5 to $100 \mathrm{mml} / \mathrm{L}$ ) and concentration of $\mathrm{NAD}^{+}$was $10 \mathrm{mmol} / \mathrm{L}$, the reaction velocities of OsNAD-ME ${ }_{1}$ were determined as shown in Figure $4 \mathrm{a}$. When $\mathrm{NAD}^{+}$was the limiting substrate $(25$ to $500 \mu \mathrm{mol} / \mathrm{L}$ ) and concentration of malate was $10 \mathrm{mmol} / \mathrm{L}$, the reaction velocities of OsNAD-ME ${ }_{1}$ were shown in Figure 4c. The data from Figure $4 \mathrm{a}$ and $\mathrm{c}$ were further analyzed using Lineweaver-Burk reciprocal plots (Figure $4 \mathrm{~b}$ and $\mathrm{d}$ ). The $K_{\mathrm{m}}$ values of OsNAD-ME ${ }_{1}$ determined at $\mathrm{pH} 6.4$ for $\mathrm{NAD}^{+}$and malate were 0.10 and 15.98 $\mathrm{mmol} / \mathrm{L}$, respectively (Table 2 ). The activity of AtNAD$M E_{1}$ in the direction of malate decarboxylation, examined at several $\mathrm{NAD}^{+}$concentrations and at a saturating fixed level of L-malate, showed a hyperbolic response. Nevertheless, a sigmoidal behavior was observed when varying the L-malate concentration at a saturating level of $\mathrm{NAD}^{+}$(Tronconi et al 2010). The kinetic parameters of purified OsNAD-ME 1 were described in. The $k_{\text {cat }}$ value for OsNAD-ME ${ }_{1}$ was $36.38 \mathrm{~s}^{-1}$, meanwhile, the $k_{\mathrm{cat}} / K_{\mathrm{m}}$ values for $\mathrm{NAD}^{+}$and malate were 357.12 and 2.28, respectively (Table 2). For comparison, the $k_{\text {cat }}$ value of NAD-ME from E. coli $\mathrm{K} 12$ was $134.39 \mathrm{~s}^{-1}$. In addition, apparent $K_{\mathrm{m}, \mathrm{NAD}}$ and $K_{\mathrm{m} \text {,malate }}$ of ECNAD-ME determined at $\mathrm{pH} 7.2$ for Lmalate and NAD were $0.097 \pm 0.038$ and $0.420 \pm 0.174$ $\mathrm{mmol} / \mathrm{L}$, respectively, (Wang et al., 2007).

The OsNAD-ME ${ }_{1}$ utilized $\mathrm{NAD}^{+}$preferentially to NADP ${ }^{+}$ as a coenzyme. When $\mathrm{NADP}^{+}(10 \mathrm{mmol} / \mathrm{L})$ was used as a substrate instead of $\mathrm{NAD}^{+}$, and the maximum activity of OsNAD-ME ${ }_{1}$ was $64.47 \%$ of the maximum activity with $\mathrm{NAD}^{+}$(Figure 5), which was similar with the result of NAD-ME from Tritrichomonas foetus hydrogenosomes using $\mathrm{NADP}^{+}$(activity was maximal $65 \%$ of the activity with $\mathrm{NAD}^{+}$) (Hrdý and Mertens, 1993). However, when $\mathrm{NAD}^{+}$(up to $4 \mathrm{mmol} / \mathrm{L}$ ) was used as a substrate in place of $\mathrm{NADP}^{+}$, neither NADP-ME${ }_{2}$ nor NADP-ME ${ }_{3}$ from $O$. sativa L. showed any activity (Cheng et al., 2006). More also, Hsieh et al. (2006) showed that the single mutation of Gln362 to Lys in human mitochondrial-NAD-ME changed it to an NADP-dependent enzyme, suggesting an important role of Gln362 in the transformation of cofactor specificity. OsNAD-ME ${ }_{1}$ is a metalloenzyme containing $\mathrm{Mg}^{2+}$ as a cofactor. Our results indicated that the deficiency of $\mathrm{Mg}^{2+}$ resulted in the failure of OsNAD$M E_{1}$ to display any activity (Table 2). The activity of NADME from $T$. foetus hydrogenosomes was also completely dependent on the presence of $\mathrm{Mg}^{2+}$ or $\mathrm{Mn}^{2+}$ (Hrdý and Mertens, 1993). During the catalytic process of malic enzyme, binding metal ion induced a conformational change within the enzyme from the open form to an intermediate form, which upon binding of L-malate, transformed further into a catalytically competent closed form (Chang et al., 2007).

Previous researches showed that NADP-ME expression and NADP-ME activity in rice were up-regulated by salts and osmotic stresses and rice cytoNADP-ME like NADP-ME in other spices played a role in enhancing tolerance of plants (Liu et al., 2007; Cheng et al., 2007; 
a

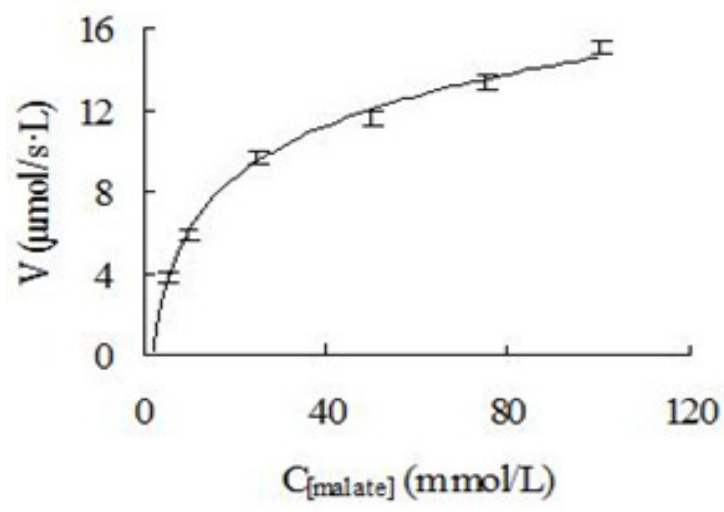

C

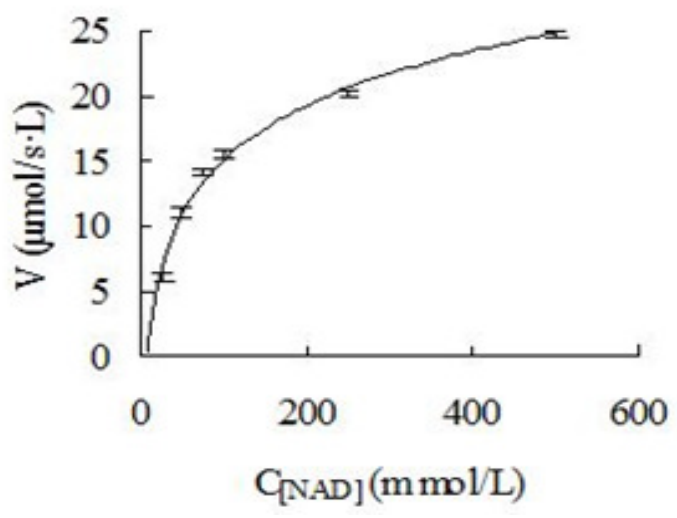

$\mathrm{b}$

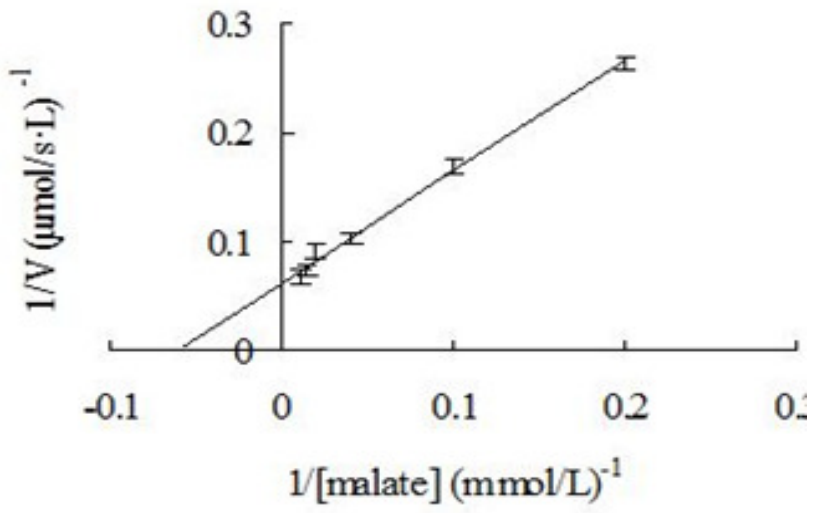

d

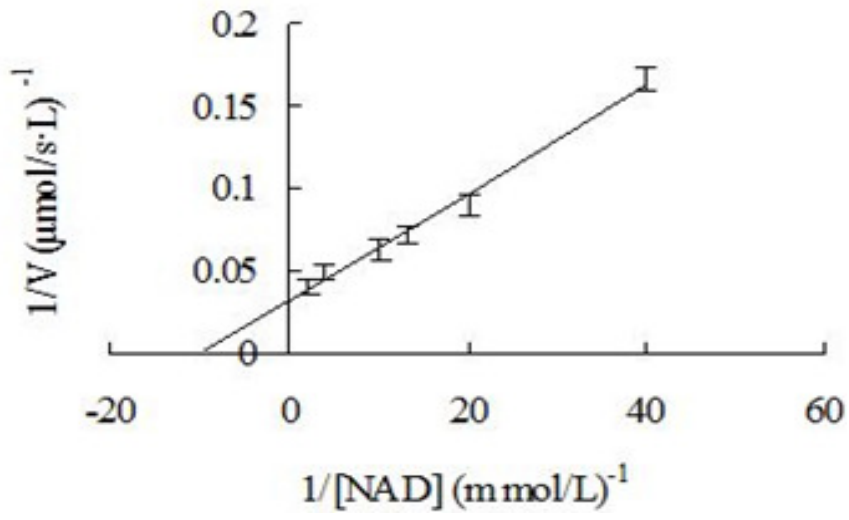

Figure 4. Analysis of reaction kinetics of purified OsNAD-ME ${ }_{1}$ recombinant proteins. Assays of OsNAD-ME 1 were performed at the optimum $\mathrm{pH}$ 6.4. The steady-state parameters $K_{\mathrm{m}}$ were determined by fitting the data to the Michaelis-Menten equation. (a) Reaction velocities were determined by changing malate concentration in the range of 5 to $100 \mathrm{mmol} / \mathrm{L}$ with 10 $\mathrm{mmol} / \mathrm{L}$ of $\mathrm{NAD}^{+}$. (b) Lineweaver-Burk reciprocal plots of the data from (a). (c) Reaction velocity assays were carried out by changing $\mathrm{NAD}^{+}$concentration in the range of 25 to $500 \mu \mathrm{mol} / \mathrm{L}$, and concentration of malate was $10 \mathrm{mmol} / \mathrm{L}$. (d) LineweaverBurk reciprocal plots of the data from (c). The results were the means of triplicate determinations. The linear correlation coefficients of regression were 0.9953 for (b) and 0.9906 for $(d)$.

Table 1. Purification of OsNAD-ME 1 recombinant proteins from E. coli BL21 cells.

\begin{tabular}{|c|c|c|c|c|c|c|}
\hline $\begin{array}{l}\text { Recombinant } \\
\text { enzyme }\end{array}$ & Purification step & $\begin{array}{l}\text { Total protein } \\
(\mathrm{mg})\end{array}$ & $\begin{array}{c}\text { Total activity } \\
(\mu \text { katal) }\end{array}$ & $\begin{array}{c}\text { Specific } \\
\text { activity } \\
(\mu \mathrm{katal} / \mathrm{g})\end{array}$ & $\begin{array}{l}\text { Purification } \\
\text { fold }\end{array}$ & $\begin{array}{c}\text { Recovery } \\
(\%)\end{array}$ \\
\hline \multirow{3}{*}{ OsNAD-ME ${ }_{1}^{a}$} & \multirow{3}{*}{$\begin{array}{l}\text { Crude extract } \\
\text { Soluble protein } \\
\text { fraction } \\
\text { Cleavage of GST tag }\end{array}$} & 182.05 & 4.35 & 23.90 & 1 & 100 \\
\hline & & 100.93 & 3.75 & 37.20 & 1.56 & 86.28 \\
\hline & & 5.78 & 3.05 & 527.84 & 22.08 & 70.11 \\
\hline
\end{tabular}

${ }^{\mathrm{a}}$ Starting material was about $2.11 \mathrm{~g}$ (wet weight) of $E$. coli BL21 cultured in $1 \mathrm{~L} 2 \times \mathrm{YT}$ medium. ${ }^{\mathrm{b}}$ One unit activity of OsNAD-ME 1 was defined as the amount of enzyme resulting in the production of $1 \mathrm{~mol}$ of NADH per second in the standard reaction mixture containing $50 \mathrm{mmol} / \mathrm{L} \mathrm{Tris-} \mathrm{HCl}$ (pH 6.4 ), $10 \mathrm{mmol} / \mathrm{L} \mathrm{MgCl} 2,0.5 \mathrm{mmol} / \mathrm{L} \mathrm{NAD}$ and $10 \mathrm{mmol} / \mathrm{L} \mathrm{L}$-malate

Shao et al., 2011). OsNAD-ME dependent malic enzyme family, is estimated to perform similar biochemical and defensive function with NADP-
MEs in rice. Nevertheless, there has been no report about the tolerance of OsNAD-ME ${ }_{1}$ to stress yet. Therefore, the results of purification and characterization 
Table 2. Kinetic parameters of OsNAD-ME 1 purified from E. coli BL21.

\begin{tabular}{ll}
\hline Parameter & Value \\
\hline Optimum pH & 6.4 \\
Optimum temperature $\left({ }^{\circ} \mathrm{C}\right)$ & 35 \\
$\mathrm{~K}_{\mathrm{cat}}{ }^{\mathrm{a}}\left(\mathrm{s}^{-1}\right)$ & 36.38 \\
$\mathrm{~K}_{\mathrm{m} \text { NAD }}(\mathrm{mmol} / \mathrm{L})$ & 0.10 \\
$\mathrm{~K}_{\text {cat }} / \mathrm{K}_{\mathrm{m} \text { NAD }}$ & 357.12 \\
$\mathrm{~K}_{\mathrm{m} \text { malate }}(\mathrm{mmol} / \mathrm{L})$ & 15.98 \\
$\mathrm{~K}_{\text {cat }} / \mathrm{K}_{\mathrm{m} \text { malate }}$ & 2.28 \\
Maximum activity using NADP & $\mathrm{NAD}^{+}(\%)$ \\
Activity in the absence of $\mathrm{Mg}^{2+}$ & 64.47 \\
\hline
\end{tabular}

${ }^{\mathrm{a}}$ Measurements were made at $\mathrm{pH} 6.4 ;{ }^{\mathrm{b}} \mathrm{ND}$, no activity was detected.

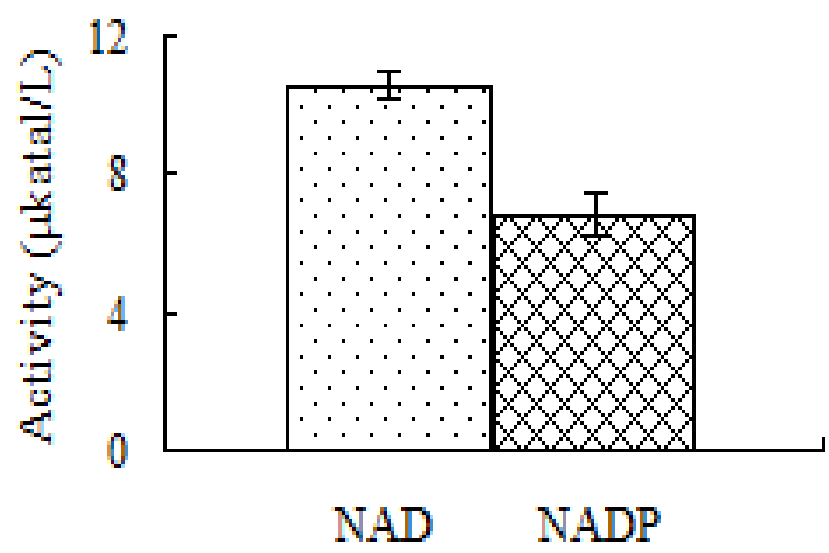

Figure 5. Comparison of the maximum activities of OsNAD$\mathrm{ME}_{1}$ between using NAD ${ }^{+}$and $\mathrm{NADP}^{+}$as coenzyme. The standard reaction mixture contained $50 \mathrm{mmol} / \mathrm{L}$ Tris- $\mathrm{HCl}(\mathrm{pH}$ 6.4), $10 \mathrm{mmol} / \mathrm{L} \mathrm{MgCl}, 0.5 \mathrm{mmol} / \mathrm{L} \mathrm{NAD}{ }^{+}$and $10 \mathrm{mmol} / \mathrm{L} \mathrm{L}-$ malate in a final concentration. The values indicated the means of three independent replications.

of the recombinant enzyme in this work will be beneficial to the resistance studies of OsNAD-ME ${ }_{1}$ in rice.

\section{Conclusion}

In this paper, we successfully expressed GST-OsNAD$\mathrm{ME}_{1}$ fusion proteins in E. coli BL21 and the optimal culture and purification procedure for generating milligram amounts of homogeneous recombinant proteins were determined. The amount of OsNAD-ME ${ }_{1}$ recombinant proteins was enough for antibody production, which might be useful for future study of the function of OsNAD-ME ${ }_{1}$. The recombinant protein was active in vitro after the cleavage of GST tag. The $k_{\text {cat }}$ value determined at pH 6.4 was $36.38 \mathrm{~s}^{-1}$ and the $K_{\mathrm{m}}$ values for $\mathrm{NAD}^{+}$and malate were 0.10 and $15.98 \mathrm{mmol} / \mathrm{L}$, respectively. Although, the efficiencies were different, OsNAD-ME ${ }_{1}$ could use either coenzyme $\mathrm{NAD}^{+}$or $\mathrm{NADP}^{+}$.

\section{REFERENCES}

Artus NN, Edwards GE (1985). Properties of leaf NAD-malic enzyme from the inducible crassulacean acid metabolism species Mesembryanthemum crystallinum. Plant Cell Physiol., 26: 341-350.

Bologna FP, Andreo CS, Drincovich MF (2007). Escherichia coli malic enzymes: two Isoforms with substantial differences in kinetic properties, metabolic regulation, and structure. J. Bacteriol. 189: 5937-5946.

Burnell JN (1987). Photosynthesis in phosphoenolpyruvate carboxykinase-type C4 species: properties of NAD-malic enzyme from Urochloa panicoides. J. Plant Physiol., 14:517-525.

Casati P, Drincovich MF, Edwards GE, Andreo CS (1999). Malate metabolism by NADP-malic enzyme in plant defense. Photosynth. Res., 61(2): 99-105.

Chang GG, Tong $L$ (2003). Structure and function of malic enzymes, a new class of oxidative decarboxylases. Biochemistry 42:12721-12733

Chang HC, Chaang GG (2003). Involvement of single residue Tryptophan 548 in the quaternary structural stability of pigeon cytosolic malic enzyme. J. Biol. Chem. 278: 23996-24002.

Chang HC, Chen LY, Lu YH, Li MY, Chen YH, Lin CH, Chang GG (2007). Metal lons stabilize a dimeric molten globule state between the open and closed forms of malic enzyme. Biophys. J. 93: 39773988. 
Chang HC, Chou WY, Chang GG (2002). Effect of metal binding on the structural stability of pigeon liver malic enzyme. J. Biol. Chem. 277: 4663-4671.

Cheng YX, Long M (2007). A cytosolic NADP-malic enzyme gene fromrice (Oryza sativa L.) confers salt tolerance in transgenic Arabidopsis. Biotechnol. Lett., 29: 1129-1134.

Cheng YX, Takano T, Zhang XX, Yu S, Liu DL, Liu SK (2006). Expression, purification, and characterization of two NADP-malic enzymes of rice (Oryza sativa L.) in Escherichia coli. Protein. Expres. Purif., 45: 200-205.

Duvall MR, Saar DE, Grayburn WS, Holbrook GP (2003). Complex transitions between $\mathrm{C} 3$ and $\mathrm{C} 4$ photosynthesis during the evolution of Paniceae: a phylogenetic case study emphasizing the position of Steinchisma Hians (Poaceae), A C3-C4 intermediate. Plant Sci. 164: 949-958.

Fu ZY, Zhang ZB, Hu XJ, Shao HB, Ping X (2009). Cloning, identification, expression analysis and phylogenetic relevance of two NADP-dependent malic enzyme genes from hexaploid wheat. C. R. Biologies, 332: 591-602.

Fukuda W, Ismail YS, Fukui T, Atomi H, Imanaka T (2005). Characterization of an archaeal malic enzyme from the hyperthermophilic archaeon Thermococcus kodakaraensis KOD1. Archaea. 1: 293-301.

Haezlewood JL, Tonti-Filippini J, Verboom RE, Millar AH (2005). Combining experimental and predicted datasets for determination of the subcellular location of proteins in Arabidopsis. Plant Physiol. 139: 598-609.

Haezlewood JL, Tonti-Filippini JS, Gout AM, Day DA, Whelan J, Millar $\mathrm{AH}$ (2004). Experimental analysis of the Arabidopsis mitochondrial proteome highlights signalling and regulatory components, provides assessment of targeting prediction programs, and indicates plantspecific mitochondrial proteins. Plant Cell. 16: 241-256.

Haezlewood JL, Verboom RE, Tonti-Filippini J, Small I, Millar AH (2007). SUBA: the Arabidopsis subcellular database. Nucleic Acids Res. 35: 213-218.

Hrdý I, Mertens E (1993). Purification and partial characterization of malate dehydrogenase (decarboxylating) from Tritrichomonas foetus hydrogenosomes. Parasitology, 107: 379-385.

Hsieh JY, Liu GY, Chang GG, Hung HC (2006). Determinants of the Dual Cofactor Specificity and Substrate Cooperativity of the Human Mitochondrial $\mathrm{NAD}(\mathrm{P})^{+}$-dependent Malic Enzyme: Functional Roles of Glutamine 362. J. Biol. Chem. 281: 23237-23245.

Hui CC, Gu GC (2003). Involvement of Single Residue Tryptophan 548 in the Quaternary Structural Stability of Pigeon Cytosolic Malic Enzyme. J. Biol. Chem., 278: 23996-24002.

Liu SK, Cheng YX, Zhang XX, Guan QJ, Nishiuchi S, Hase K, Takano T (2007). Expression of an NADP-malic enzyme gene in rice (Oryza sativa L.) is induced by environmental stresses: over-expression of the gene in Arabidopsis confer salt and osmotic stress tolerance. Plant Mol. Biol., 64: 49-58.
Long LL, Wang JL, Berry JO (1994). Cloning and analysis of the C4 NAD-dependent malic enzyme of amaranth mitochondria. J. Biol. Chem., 269: 2827-2833.

Marshall DM, Muhaidat R, Brown NJ, Liu Z, Stanley S, Griffiths H, Sage RF, Hibberd JM (2007). Cleome, a genus closely related to Arabidopsis $\mathrm{z}$, contains species spanning a developmental progression from C3 to C4 photosynthesis. Plant J. 51: 886-896.

Maurino VG, Gerrard Wheeler MC, Andreo CS, Drincovich MF (2009). Redundancy is sometimes seen only by the uncritical: Does Arabidopsis need six malic enzyme isoforms? Plant Sci. 176: 715721.

Shao HB, Liu ZH, Zhang ZB, Chen QJ, Chu LY Brestic M (2011). Biological roles of crop NADP-malic enzymes and molecular mechanisms involved in abiotic stress. Afr. J. Biotechnol., 10(25): 4947-4953.

Sutherland MW (1991). The generation of oxygen radicals during host plant responses to infection. Physiol. Mol. Plant Pathol., 39: 79-93.

Tronconi MA, Fahnenstich H, Gerrard Wheeler MC, Andreo CS, Flügge UI, Drincovich MF, Maurino VG (2008). Arabidopsis NAD-Malic enzyme functions as a homodimer and heterodimer and has a major impact on nocturnal metabolism. Plant Physiol. 146: 1540-1552.

Tronconi MA, Gerrard Wheeler MC, Maurino VG, Drincovich MF, Andreo CS (2010). NAD-Malic enzymes of Arabidopsis thaliana display distinct kinetic mechanisms that support differences in physiological control. Biochem. J. 430: 295-303.

Tronconi MA, Maurino VG, Andreo CS, Drincovich MF (2010). Three different and tissue-specific NAD-malic enzymes generated by alternative subunit association in Arabidopsis thaliana. J. Biol. Chem. 285: 11870-11879.

Wang JX, Tan HD, Zhao ZB (Kent) (2007). Over-expression, purification, and characterization of recombinant NAD-malic enzyme from Escherichia coli K12. Protein Expres. Purif., 53:97-103

Willeford KO, Wedding RT (1987). Evidence for a multiple subunit composition of plant NAD malic enzyme. J. Biol. Chem., 262:84238429.

Winning BM, Bourguignon J, Leaver CJ (1994). Plant mitochondrial NAD+-dependent malic enzyme. cDNA cloning, deduced primary structure of the 59- and 62-kDa subunit, import, gene complexity and expression analysis, J. Biol. Chem. 269: 4780-4786. 